\title{
Oral supplementation of probiotics on the performance and gut histo-morphology of suckling piglets
}

\section{Lisandro Alfredo Haupenthal ${ }^{1^{*}}$ (D) João Garcia Caramori Júnior ${ }^{1}$ (i) Gerusa da Silva Salles Corrêa ${ }^{1}$ Bruno Alexander Nunes Silva ${ }^{2}$ (1)}

${ }^{1}$ Programa de Pós-graduação em Ciência Animal, Universidade Federal de Mato Grosso (UFMT), 78060-900, Cuiabá, MT, Brasil. E-mail: lisandrohaupenthal@hotmail.com. "Corresponding author.

${ }^{2}$ Instituto de Ciência Animal, Universidade Federal de Minas Gerais (UFMG), Montes Claros, MG, Brasil.

ABSTRACT: The effects of the oral supplementation of probiotics on the performance and intestinal histo-morphology of the duodenal, jejunal, and ileal mucosa, comparing with two different genetic lines (purebred Large White or crossbred Large White $x$ Landrace) of suckling piglets were evaluated between 2 and 19 days of age. In total, 276 piglets were distributed according to a completely randomized experimental design in a $2 \times 3$ factorial arrangement, with four replicates each. Treatments consisted of two genetic lines (130 purebred Large White and 146 crossbred Large White $x$ Landrace piglets), two different probiotic products (probiotic bacteria or a combination of yeast and probiotic bacteria), and a control (basal diet with no addition). Probiotics increased the average daily weight gain $(P=0.02)$, independently of genetic line, but did not influence $(P>0.10)$ average daily feed intake. Crossbred piglets presented higher average daily feed intake ( $P=0.03)$ than purebreds. The incidence of diarrhea was not significantly different $(P>0.10)$ among the treatments. Intestinal histo-morphometric parameters were not influenced by genetic lines $(P>0.10)$. However, the piglets fed with the probiotic products exhibited higher duodenal villi compared with the control $(P=0.01)$. In conclusion, piglets that received oral probiotics improved intestinal health and average daily weight gain, independent of the genetic lines. Higher duodenal villus were measured in P2 and P3 (450.37 $\mu m$ and $435.62 \mu \mathrm{m}$, respectively) compared with the control group P1 (309.25 $\mu \mathrm{m} ; \mathrm{P}=0.01)$. Higher average daily weight gain was obtained in P2 and P3 (259.55 g and 250.50 g, respectively) compared with P1 (221.9 g; P=0.02).

Key words: Probiotics, diarrhea, intestinal morphometry, pigs, performance.

Suplementação oral de probióticos sobre o desempenho e histo-morfologia intestinal de leitões lactentes

RESUMO: Avaliou-se o efeito da suplementação oral de probióticos em forma líquida em leitões lactentes (2 aos 19 dias de idade), de linhagem pura Large White e cruzamento Landrace e Large White, sobre ganho de peso diário, consumo de ração, incidência de diarreia e características morfo-histológicas da mucosa do intestino delgado, altura, largura e perímetro das vilosidades e profundidade das criptas. Um total de 276 leitões foram distribuídos em um delineamento inteiramente casualizado com arranjo fatorial $2 x 3$, com quatro repetições. Os tratamentos consistiram de duas linhagens genéticas, 130 leitões Large White puros e 146 leitões provenientes do cruzamento das raças Landrace e Large White, duas combinações distintas de microrganismos, bactérias probióticas ou combinação de levedura e bactérias probióticas e um grupo controle alimentado com uma dieta basal, sem adição de antibióticos e promotores de crescimento. A suplementação com probióticos aumentou o ganho médio de peso diário de leitões lactentes $(P=0,02)$, independente da linhagem, e não influenciou ( $P>0,10)$ o consumo médio diário de ração. $O$ cruzamento das raças Landrace e Large White apresentou maior consumo médio diário de ração $(P=0,03)$. Não houve diferença significativa na incidencia de diarreia $(P>0,10)$ entre os tratamentos. A histo-morfometria intestinal não foi significativamente diferente entre as linhagens genéticas $(P>0,10)$. Os leitões que receberam probióticos apresentaram maior altura de vilosidade em duodeno $(P=0,01)$. Concluiu-se que os leitões que receberam probióticos orais melhoraram a histo-morfologia intestinal e o ganho médio diário de peso, independentemente das linhas genéticas. As maiores vilosidades duodenais foram medidas em P2 e P3 (450,37 $\mu$ m e 435,62 $\mu \mathrm{m}$, respectivamente) em comparação com o grupo controle P1 (309,25 $\mu \mathrm{m} ; \mathrm{P}=0,01)$. Maior ganho de peso médio diário foi obtido em P2 e P3 (259,55 g e 250,50 g, respectivamente) em comparação com P1 (221,9 g; $P=0,02)$.

Palavras chave: probióticos, diarreia, morfometria intestinal, suínos, desempenho.

\section{INTRODUCTION}

The growing concern with the withdrawal of antibiotics in pig production, coupled with the need to increase the zootechnical performance of livestock, motivates the search for alternatives that reduce the potential negative impact on performance by reducing antibiotics and growth promoters administered to animals intended for human consumption. The negative effects on growth performance of removing 
antibiotics from pig production require changes in management and nutritional strategies.

Currently, the concept of using probiotics is advancing, most likely because of research efforts that contribute to the knowledge of the composition of microbiota and allow the identification of other substances that influence intestinal colonization. Concomitantly with this progress is the perception that several beneficial microorganisms are affected by probiotics and also that they can contribute to intestinal health. The gut microbiome has long been known to play fundamentally important roles in the animal health and the well-being of its host. As such, the establishment and maintenance of a beneficial gut microbiota early in life is crucial in pigs, since early gut colonizers are pivotal in the establishment of permanent microbial community structures affecting the health and growth performance of pigs later in life (GUEVARRA et al., 2019).

The most effective approaches are based on prevention and recognize that early life strategies that promote a resilient, diverse and healthy microbiota have greater long-term potential. Evidence of the important relationship between the structure and function of the microbial community, the use of probiotics and the health of the host is being reported in several studies of its kind. In order to answer questions related to the benefit to animal health, controlled studies must establish direct links between the probiotic and the health in the target host. The level of evidence can be demonstrated through the effect on the animal's zootechnical performance, in addition to morphological characteristics of the intestinal mucosa, which demonstrate the benefit conferred to health. To date, numerous studies have demonstrated the health benefits of a variety of probiotics in healthy pig populations and those challenged by situations of intestinal microbiota imbalance.

The probiotics consist of specific live microorganisms that, when orally administered, multiply in the digestive tract of animals and compete with microbial pathogens for intestinal binding sites and nutrients. Probiotics use live microorganisms, serve as nutrients for beneficial microorganisms by the host, including administered probiotic strains and indigenous microorganisms. Consequently, they promote better nutrient utilization and reduce the replication of pathogenic bacteria in the gastrointestinal tract (CHO et al., 2011). Various initiatives which aimed to identify the microbiota of healthy swine gut have previously been reported, with an emphasis on the dominant members of the community as influenced by age, diet and disease state of the animal (VALERIANO et al., 2016).
According to LIAO et al. (2017), the management of intestinal micro-ecosystem is one of the common strategies applied to prevent diarrhea, improve health status, and enhance growth performance of pigs in modern intensive production systems. BOMBA et al. (2002) mentioned that the efficacy of probiotics is influenced by several factors, such as health and nutritional statuses, age, stress, and genetics. Modern genetic lines of pigs may present different nutrient absorption efficiency, which may affect their live performance. The pig genetic background can be considered as a predisposing factor to gut infection resulting in gut microbial shifts (GUEVARRA et al., 2019).

The objective of this study was to evaluate the effects of the oral supplementation of different probiotic products on the daily weight gain, daily feed intake, incidence of diarrhea, and histo-morphological characteristics of the intestinal mucosa of suckling piglets.

\section{MATERIALS AND METHODS}

The procedures of this experiment were approved by the Committee of Ethics on Animal Use of the School of Agriculture, Veterinary Medicine, and Animal Science of the Federal University of Mato Grosso (UFMT).

\section{Animals and experimental procedure}

The study was carried out in a farrowing room of a commercial sow farm located in the north of the state of Mato Grosso, in the mid-western region of Brazil (latitude $13^{\circ} 05^{\prime} 04^{\prime \prime}$; longitude $56^{\circ}$ $05^{\prime} 16^{\prime \prime}$, altitude $\left.450 \mathrm{~m}\right)$. The local climate is Aws (hot, tropical, alternately dry and wet), according to Köppen's classification.

Two hundred and seventy six piglets were distributed according to a completely randomized experimental design in a $2 \times 3$ factorial arrangement. Treatments consisted of two genetic lines, purebred Large White (L1) and crossbred Landrace x Large White (L2) piglets, which were fed with two different commercial probiotic products available in the market (P2 and P3) and no probiotic (P1), which was considered as the control group and used to compare the effects of $\mathrm{P} 2$ and $\mathrm{P} 3$. The $\mathrm{P} 2$ product contained Lactobacillus plantarum $\left(2.0 \times 10^{6} \mathrm{CFU} / \mathrm{g}\right)$, L. casei $\left(1.0 \times 10^{6} \mathrm{CFU} / \mathrm{g}\right)$, L. gasseri $\left(1.0 \times 10^{6} \mathrm{CFU} / \mathrm{g}\right)$, and Enterococcus faecium $\left(1.0 \times 10^{6} \mathrm{CFU} / \mathrm{g}\right)$. The $\mathrm{P} 3$ product was a combination of Bifidobacterium bifidum $\left(3.33 \times 10^{6}\right.$ CFU/g), L. acidophilus $\left(3.33 \times 10^{6} \mathrm{CFU} / \mathrm{g}\right)$, L. plantarum $\left(1.66 \times 10^{6} \mathrm{CFU} / \mathrm{g}\right)$, E. faecium $\left(1.66 \times 10^{6} \mathrm{CFU} / \mathrm{g}\right)$ and Saccharomyces cerevisiae $\left(3.33 \times 10^{5} \mathrm{CFU} / \mathrm{g}\right)$. 
On d1 post-farrowing (d1 of the experiment), one hundred and thirty piglets born from 12 purebred Large White (L1) and one hundred and forty six born from crossbred Large White x Landrace (L2) with parity ranging from 3 to 5 were distributed in a completely randomized design in a $2 \times 3$ factorial arrangement. The sows were individually housed in the same farrowing room.

Individual piglets in the P2 and P3 treatments on $\mathrm{d} 1$ received by oral administration of a single dose of $2 \mathrm{~mL}$ and $1 \mathrm{~mL}$ of $\mathrm{P} 2$ and $\mathrm{P} 3$ according to the manufacturers' recommendations. Water and creep feed were offered ad libitum after d 8 of the experiment. The creep diet (Table 1) was formulated to supply the nutritional requirements of suckling piglets and contained the essential amino acid to digestible lysine ratios proposed by The Brazilian Nutrient Recommendation for ROSTAGNO, H.S., et al. (2011).

On d 2 (3 days of age), piglets were submitted to routine procedures, including tail docking with post-section cauterization, intramuscular iron injection, and teeth clipping. Sows were fed a lactation feed formulated to supply their nutritional requirements for this phase. The lactation feed was based on corn and soybean meal, and contained the calculated values of
$1.195 \%$ digestible lysine, $3.350 \mathrm{kcal} / \mathrm{kg}$ metabolizable energy, $1.004 \%$ calcium, $0.449 \%$ available phosphorus. The digestible essential amino acid to digestible lysine ratios followed those recommended by The Brazilian Nutrient Recommendation for ROSTAGNO, H.S., et al. (2011).

\section{Measurements and collected parameters}

Piglets were individually weighed on a digital scale at the beginning (d 1) and end (d 18) of the experiment. Offered feed and feed refusals in the troughs were weighed using a digital scale per pen daily. Piglet fecal texture was scored every morning per pen during the experimental period. Feces were scored daily according to fecal texture as normal (F1), pasty (F2), or watery (F3). The F3 indicated diarrhea, according to the methodology of SOBESTIANSKY et al. (1998). At the end of the experiment (d 18), one piglet per experimental unit $(\mathrm{n}=24)$, with similar body weight to the litter's average body weight, was selected, stunned, and sacrificed by carotid artery section. At necropsy, $5 \mathrm{~cm}$ sections of the duodenum, jejunum, and ileum were collected.

The intestinal sections were sampled for the morpho-histological evaluation at the Veterinary Pathology Laboratory of the Federal University of

Table 1 - Ingredients and calculated composition of the creep diet fed to suckling piglets during the experimental from $\mathrm{d} 8$ to 18 .

\begin{tabular}{|c|c|}
\hline Ingredients & Inclusion (\%) \\
\hline Ground corn & 19.470 \\
\hline Soybean meal & 14.000 \\
\hline Spray-dried plasma & 5.000 \\
\hline Dicalcium phosphate & 1.430 \\
\hline Limestone & 0.330 \\
\hline Sugar & 5.000 \\
\hline Milk whey & 17.600 \\
\hline Lysine & 0.430 \\
\hline Nursing piglet complete supplement & 36.740 \\
\hline \multicolumn{2}{|c|}{ 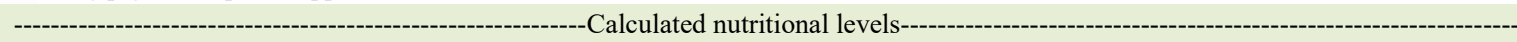 } \\
\hline Crude protein $(\%)$ & 20.150 \\
\hline Fat $(\%)$ & 4.361 \\
\hline Crude fiber $(\%)$ & 1.942 \\
\hline Calcium $(\%)$ & 0.740 \\
\hline Available phosphorus (\%) & 0.670 \\
\hline Metabolizable energy (Mcal/kg) & 3.50 \\
\hline Digestible lysine $(\%)$ & 1.55 \\
\hline Methionine (\%) & 0.63 \\
\hline Threonine (\%) & 1.11 \\
\hline Tryptophan (\%) & 0.26 \\
\hline Lactose $(\%)$ & 21.38 \\
\hline
\end{tabular}

Ciência Rural, v.50, n.10, 2020. 
Mato Grosso. Tissues were fixed in $10 \%$ formalin, rinsed in $70 \%$ alcohol, dehydrated in ethanol series, cleared in xylol, and embedded in paraffin, after which $5-\mu \mathrm{m}$ sections were cut and stained with hematoxylin and eosin, according to BEHMER et al. (1976). Villus height (VH), width (VW), and perimeter (VP), and crypt depth (CD) of each intestinal segment were measured using an image-analyzing software (Axion Vision 4.8.2.0 ZEISS $^{\circledR}$ ), coupled to a microscope (Axion Imager A2 ZEISS ${ }^{\circledR}$ ), and expressed as the average of the measurements taken at five different areas of a same slide of each intestinal segment of each experimental unit.

\section{Calculations and statistical analyses}

Maximum and minimum environmental temperatures and relative humidity levels were grouped and analyzed for the entire experimental period. Individual ADWG was calculated as the difference between final body weight (d 18) and initial body weight ( $\mathrm{d}$ 1) divided by the number of experimental days $(n=18)$. ADFI was calculated as daily feed offer minus daily feed residues per pen. Sow average daily milk production was calculated according to the equation proposed by NOBLET \& ETIENNE (1989). Data were submitted to normality testes and analyzed using the GLM procedure of SAS package (version 8.1). Least square means were compared by the test of Tukey at $\mathrm{P}<0.05$. Effects of genetic line (L) and probiotic supply (P) were included in the statistical model.

\section{RESULTS}

Average minimum and maximum temperatures and relative humidity levels measured during the experimental period were 36 and $23{ }^{\circ} \mathrm{C}$, and 75.1 and $28.7 \%$, respectively. There was no interaction between genetic line and probiotic supply for none of the analyzed parameters.

\section{Effect of probiotic supply}

There was no influence of probiotic supply $(P>0.10)$ on piglets average daily feed intake. However, a higher average daily weight gain (ADWG; Table 2) was obtained in the piglets of P2 and $\mathrm{P} 3$ groups compared with those in the control group $(P=0.02)$. No differences $(P>0.10)$ in the incidence of diarrhea (ID) were observed among the treatments during the experimental period (Table 2). A higher average daily milk production was observed in the sows from the P3 group compared with the sows from control group and $\mathrm{P} 2(P=0.02)$.
Probiotic supply influenced intestinal mucosa morpho-histological characteristics, particularly duodenal $(P=0.01)$ and jejunal $(P=0.02)$ villus height $(\mathrm{VH})$ and ileal villus perimeter (VP; $P=0.04)$. Higher duodenal $\mathrm{VH}$ was observed in $\mathrm{P} 2$ and $\mathrm{P} 3$ as compared with P1 (Figure 1). Jejunal VH was lower in P1 piglets compared with P2 but not with P3 piglets. In the ileum, on the other hand, piglets in the $\mathrm{P} 2$ group presented a shorter villi and lower villus perimeter than those in P1 (Table 3). Villus width and crypt depth were similar in all the three groups.

\section{Effect of genetic line}

The genetic line influenced average daily feed intake $(P=0.03)$, whereas, Landrace $\mathrm{x}$ Large White crossbred piglets (L2) presented higher feed intake than Large White purebreds (Table 2). There was no effect $(P>0.10)$ of genetic line on ADWG nor on the incidence of ID during the experimental period (Table 2). No significant differences in intestinal morpho-histological parameters $(P>0.10)$ were observed between the evaluated genetic lines (Table 3). A higher average daily milk production was observed in the sows from L2 compared with L1 $(P=0.01)$.

\section{DISCUSSION}

\section{Effect of probiotic supply}

The supply of probiotics to suckling piglets did not affect their average daily feed intake or the incidence of diarrhea; however, it improved average daily weight gain, independently of genetic line. These results are different from those obtained by ROBLES-HUAYNATE et al. (2013), who observed better feed intake in suckling piglets orally supplied with a probiotic product, but no differences in weight gain or in the incidence of diarrhea. The higher average daily weight gain observed with the supply of probiotics in the present experiment may be related to better intestinal capacity of nutrient absorption, as shown by the higher duodenal and jejunal villus height measured in the probiotic-supplied piglets. Conversely, BOSI et al. (2011) and ASSIS et al. (2014) did not find any changes in the intestinal morphometry of weaned piglets fed antibiotics and prebiotics, respectively. CHOI et al. (2011), did not verified changes in the morphology of the duodenal mucosa, observed an increase in jejunal and ileal villus height when weaned piglets were fed with probiotics. However, LUNA et al. (2015) observed higher villi and deeper crypts in the duodenum and 
Table 2 - Effect of probiotic and genetic line on average daily weight gain (ADWG), average daily feed intake (ADFI), and incidence of diarrhea (ID) in piglets.

\begin{tabular}{|c|c|c|c|c|c|}
\hline \multirow[t]{2}{*}{ Parameter } & \multicolumn{3}{|c|}{ 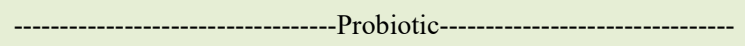 } & \multirow[t]{2}{*}{ RSD } & \multirow[t]{2}{*}{ Statistics } \\
\hline & $\mathrm{P} 1$ & $\mathrm{P} 2$ & P3 & & \\
\hline Litter size, $\mathrm{n}$ & 11.6 & 11.4 & 11.5 & & \\
\hline Weaned piglets, $\mathrm{n}$ & 10.5 & 10.9 & 11.5 & & \\
\hline ADFI, $\mathrm{g}^{-}$ & 222.8 & 224.5 & 204.9 & & \\
\hline \multicolumn{6}{|l|}{-----------.-. } \\
\hline Initial weight, $\mathrm{kg}$ & $1.69 \mathrm{a}$ & $1.51 \mathrm{~b}$ & $1.74 \mathrm{a}$ & 0.13 & $\mathrm{P} P=0.01$ \\
\hline Final weight, kg & $5.45 \mathrm{~b}$ & $5.92 \mathrm{ab}$ & $6.00 \mathrm{a}$ & 0.52 & $P P=0.01$ \\
\hline ADWG, $g$ & $221.9 b$ & $259.5 \mathrm{a}$ & $250.5 \mathrm{a}$ & 26.07 & $P P=0.02$ \\
\hline $\mathrm{ID}, \%$ & 16.67 & 15.97 & 18.75 & & \\
\hline Milk production, $\mathrm{kg} \mathrm{d}$ & $9.01 \mathrm{~b}$ & $11.53 \mathrm{ab}$ & $12.40 \mathrm{a}$ & 2.85 & $\mathrm{P} P=0.02$ \\
\hline \multicolumn{6}{|c|}{ 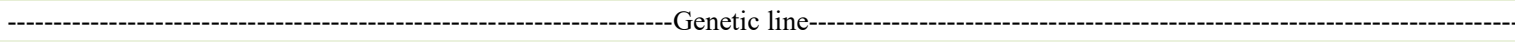 } \\
\hline Parameter & L1 & & L2 & RSD & Statistics \\
\hline Litter size, $\mathrm{n}$ & $10.8 \mathrm{~B}$ & & $12.2 \mathrm{~A}$ & 0.8 & $\mathrm{~L} P=0.01$ \\
\hline Weaned piglets, $n$ & $10.3 \mathrm{~B}$ & & $11.6 \mathrm{~A}$ & 1.1 & $\mathrm{~L} P=0.01$ \\
\hline ADFI, $g$ & $195.1 \mathrm{~B}$ & & $239.7 \mathrm{~A}$ & 47.5 & $\mathrm{~L} P=0.03$ \\
\hline \multicolumn{6}{|c|}{ 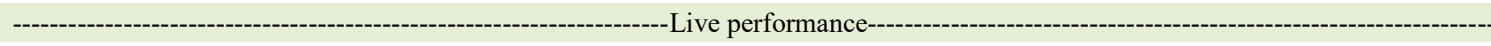 } \\
\hline Initial weight, $\mathrm{kg}$ & 1.62 & & 1.68 & & \\
\hline Final weight, kg & 5.68 & & 5.90 & & \\
\hline ADWG, $\mathrm{g}$ & 239.20 & & 248.77 & & \\
\hline $\mathrm{ID}, \%$ & 14.82 & & 19.44 & & \\
\hline Milk production, $\mathrm{kg} \mathrm{d}$ & $9.53 \mathrm{~B}$ & & $12.43 \mathrm{~A}$ & 2.85 & $\mathrm{~L} P=0.01$ \\
\hline
\end{tabular}

$\mathrm{ab}, \mathrm{AB}$ Means bearing different superscript in a row differ significantly; $\mathrm{RSD}=$ residual standard deviation; $\mathrm{P}=$ probiotic; $\mathrm{L}=$ genetic line, P1 = basal diet; P2 = probiotic product containing L. plantarum (2.0x106 CFU/g), L. casei (1.0x106 CFU/g), L. gasseri (1.0x106 $\mathrm{CFU} / \mathrm{g})$, and E. faecium $(1.0 \times 106 \mathrm{CFU} / \mathrm{g})$; and $\mathrm{P} 3$ = probiotic product containing B. bifidum $(3.33 \times 106 \mathrm{CFU} / \mathrm{g})$, L. acidophilus (3.33x106 CFU/g), L. plantarum $(1.66 \times 106 \mathrm{CFU} / \mathrm{g})$, E. faecium $(1.66 \times 106 \mathrm{CFU} / \mathrm{g})$, S. cerevisiae $(3.33 \times 105 \mathrm{CFU} / \mathrm{g})$; L1 = purebred Large White piglets; L2 = Landrace $\mathrm{x}$ Large White crossbred piglets.

ileum, as well as higher jejunal villus perimeter in weaned piglets fed diets supplemented with a prebiotic containing $\beta$-glucans compared with those fed a non-supplemented diet.

The increase in duodenal and jejunal villus height observed with the utilization of probiotic bacteria may be explained by the colonization of these intestinal segments by a higher number of saprophyte bacteria, which competitively exclude harmful microorganisms. The reduced population of potentially pathogenic bacteria may favor the proliferation of the epithelial cells of the intestinal villi. However, in the ileum, villus height and perimeter values were lower when the probiotic products were fed, independently of genetic line and therefore, other mechanisms may be associated with the observed changes of the intestinal morphology. According to GIBSON et al. (2017) the specific stimulation of bifidobacteria could be considered a probiotic effect, because the microbial ecology was based on culture methods, which we now know were insufficient to reveal the complexity of probioticinduced microbial changes. Besides that, molecularbased methods, which have since identified a broader range of members of the gut microbial community, have enabled the appreciation that more bacterial genera might utilize some probiotic substrates, by fermentation and other metabolic pathways. These microorganisms can vary depending upon the host and ecosystem under consideration.

Intestinal health is commonly associated with the integrity of intestinal mucosa (BOSI et al., 2011). The intestine is one of the main routes for the entrance of potentially pathogenic agents in the body. The most common antigens present in the intestines are feed proteins, commensal intestinal microbiota, and invading pathogens. The diarrhea observed in the present experiment was probably due to the immaturity of the digestive and immune systems of the suckling piglets, which makes them more susceptible to 


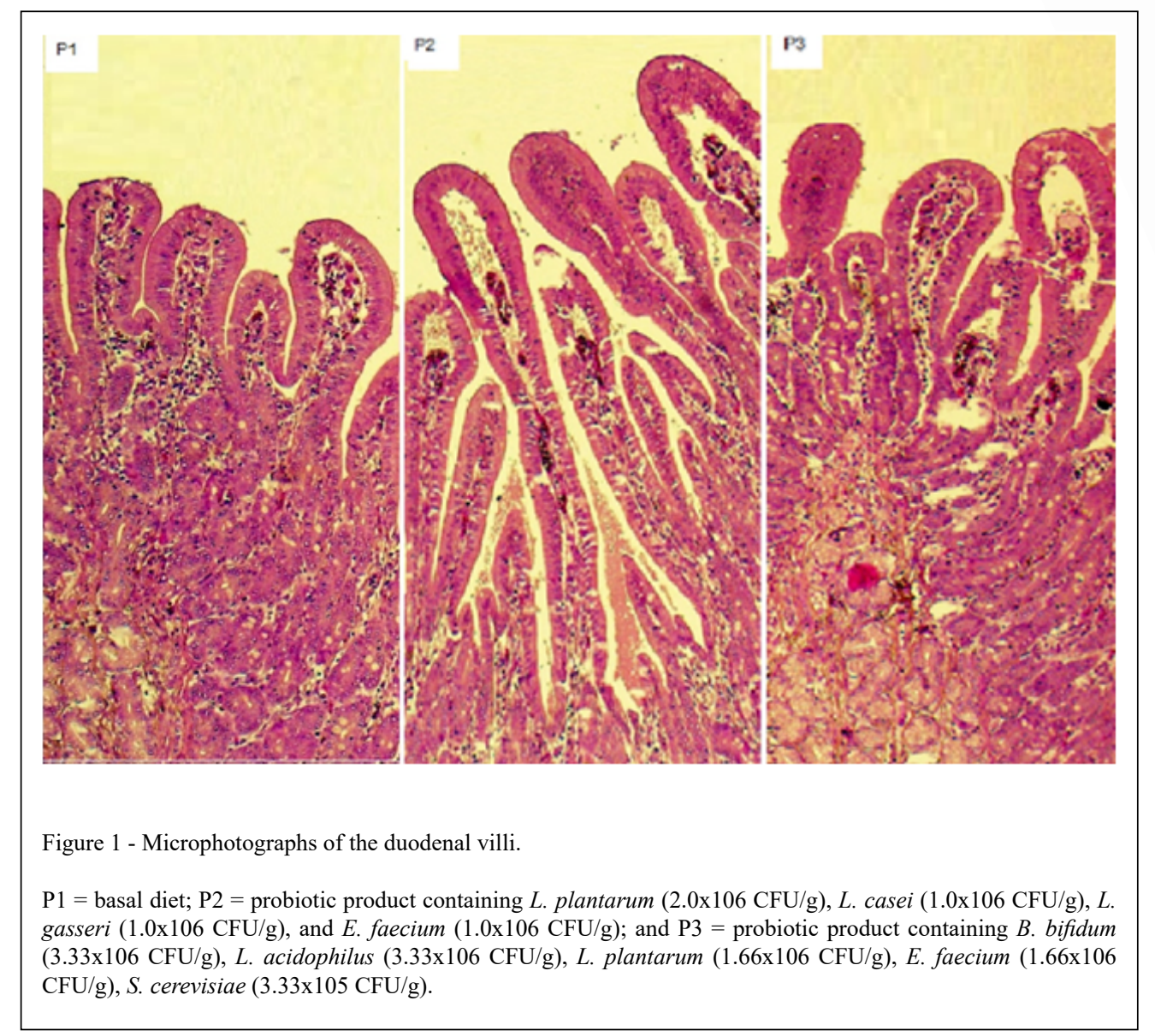

gastrointestinal disorders and to opportunistic agents than older pigs. However, the high health status of the farm where the experiment was carried out may justify the lack of differences in the incidence of diarrhea among treatments. According to VAN DER AAR et al. (2017) the composition of the gut microbiota plays an important role in the health of pigs and increasing the population of bacteria of genus Bifidobacterium and Lactobacillus in the gut may improve the health of the animals and decrease the risk of diseases. Besides that, bifidobacteria, often stimulated by specific probiotics, do not produce butyrate, so a probable scenario is that crossfeeding by other bacteria must have resulted in production of short-chain fatty acid which has been reported about the benefits of butyrate in the gut and on animal health.

The epithelium of the intestinal mucosa acts as a physical barrier against pathogens, according to YANG et al. (2012). Disturbances of this barrier function increase the permeability of the mucosa, resulting in the transport of bacteria, toxins, and other antigens present in the intestinal lumen to the subepithelial tissue, as well as impaired nutrient absorption. Therefore, the integrity of the barrier function of the intestinal mucosa is essential to ensure adequate dietary nutrient absorption and to prevent digestive disorders. The higher duodenal villi observed in the piglets fed the probiotic products demonstrates the better integrity of the mucosa in this intestinal segment, which possibly contributed for their better performance compared with the control piglets.

The higher average daily weight gain of the probiotic-fed piglets may also be related with the composition of the intestinal microbiota, as the intestinal saprophytic microbiota typically compete with potential pathogens using mechanisms that trigger intestinal immune responses. In non-ruminant animals, gastric $\mathrm{pH}$ is very low, acting both as a bactericide and a viricide; however, it varies with animal species and diet. In the intestinal lumen, the normal microbiota

Ciência Rural, v.50, n.10, 2020. 
Table 3 - Mean morpho-histometric values $(\mu \mathrm{m})$ obtained in small intestine segments as a function of the experimental treatments.

\begin{tabular}{|c|c|c|c|c|c|c|}
\hline \multirow[t]{2}{*}{ Parameter } & \multicolumn{3}{|c|}{-----------------------Probiotic--------------------- } & \multicolumn{2}{|c|}{---------Genetic line--------- } & \multirow[t]{2}{*}{ RSD } \\
\hline & $\mathrm{P} 1$ & $\mathrm{P} 2$ & P3 & L1 & L2 & \\
\hline \multicolumn{7}{|c|}{ 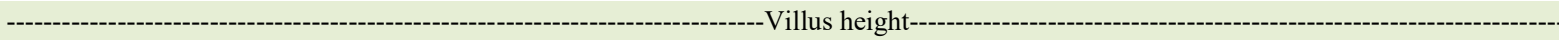 } \\
\hline Duodenum & $309.25 \mathrm{~b}$ & $450.37 \mathrm{a}$ & $435.62 \mathrm{a}$ & 404.67 & 392.17 & 88.76 \\
\hline Jejunum & $287.00 \mathrm{~b}$ & $400.74 \mathrm{a}$ & $290.75 \mathrm{~b}$ & 339.42 & 312.92 & 82.27 \\
\hline Ileum & $292.25 \mathrm{a}$ & $194.87 \mathrm{~b}$ & $249.25 \mathrm{ab}$ & 230.92 & 260.00 & 71.80 \\
\hline \multicolumn{7}{|c|}{ 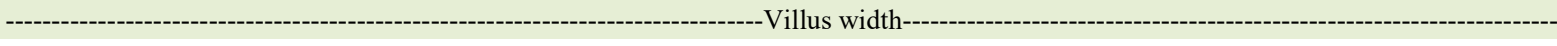 } \\
\hline Duodenum & 83.62 & 105.12 & 106.75 & 101.58 & 95.42 & 25.43 \\
\hline Jejunum & 80.12 & 97.12 & 75.12 & 87.75 & 80.50 & 17.63 \\
\hline Ileum & 83.25 & 57.37 & 74.37 & 66.75 & 76.58 & 24.42 \\
\hline \multicolumn{7}{|c|}{ - } \\
\hline Duodenum & 820.75 & 980.12 & 987.62 & 903.33 & 955.67 & 397.52 \\
\hline Jejunum & 598.00 & 725.50 & 625.50 & 704.08 & 595.25 & 168.41 \\
\hline Ileum & $630.87 \mathrm{a}$ & $417.5 \mathrm{~b}$ & $526.5 \mathrm{ab}$ & 491.50 & 558.42 & 159.24 \\
\hline \multicolumn{7}{|c|}{$\begin{array}{r}---{ }^{-} \\
-\end{array}$} \\
\hline Duodenum & 242.37 & 288.62 & 237.50 & 258.42 & 253.92 & 60.85 \\
\hline Jejunum & 160.12 & 193.75 & 129.62 & 160.92 & 161.42 & 64.29 \\
\hline Ileum & 102.37 & 95.87 & 100.37 & 100.50 & 98.58 & 28.29 \\
\hline
\end{tabular}

$\mathrm{ab}, \mathrm{AB}$ Means bearing different superscript in a row differ significantly; $\mathrm{RSD}=$ residual standard deviation; $\mathrm{P}=$ probiotic; $\mathrm{L}=$ genetic line, $\mathrm{P} 1$ = basal diet; $\mathrm{P} 2$ = probiotic product containing L. plantarum $(2.0 \times 106 \mathrm{CFU} / \mathrm{g})$, L. casei $(1.0 \times 106 \mathrm{CFU} / \mathrm{g})$, L. gasseri $(1.0 \times 106$ $\mathrm{CFU} / \mathrm{g})$, and E. faecium $(1.0 \times 106 \mathrm{CFU} / \mathrm{g})$; and $\mathrm{P} 3=$ probiotic product containing B. bifidum $(3.33 \times 106 \mathrm{CFU} / \mathrm{g})$, L. acidophilus (3.33x106 CFU/g), L. plantarum $(1.66 \times 106 \mathrm{CFU} / \mathrm{g})$, E. faecium $(1.66 \times 106 \mathrm{CFU} / \mathrm{g})$, S. cerevisiae $(3.33 \times 105 \mathrm{CFU} / \mathrm{g}) ; \mathrm{L} 1=\mathrm{purebred}$ Large White piglets; L2 = Landrace $\mathrm{x}$ Large White crossbred piglets.

maintains low $\mathrm{pH}$ values, which; however, are influenced by the diet. In suckling animals, the intestine is colonized mostly by lactobacilli, which produce large amounts of lactic and butyric acids. These acids are bacteriostatic, inhibiting the colonization of potential pathogens, and therefore, suckling piglets tend to present less digestive disorders than those submitted to early weaning.

The intestinal microbiota is essential for the maturation of the immune system and for the development of a normal intestinal morphology, strengthening the intestinal barrier function, thereby preventing the adherence of pathogenic microorganisms to the mucosa and reducing the exposure of enterocytes to allergens (YANG et al., 2012). The immune response stimulated by microbial antigens present in the intestines is more intense than that promoted by feed antigens, according to TIZARD (2002).

The efficacy of the defense against enteric pathogens in piglets depends on the combination of physical processes, such as digesta transit time in the small intestine, as well as on gastric acidification, immune response, intestinal mucosa integrity, and composition of the intestinal microbiota (ŽIVKOVIĆ et al., 2011). The beneficial effects of probiotic supplementation on the performance of the piglets observed in the present study are consistent with the findings of other studies evaluating probiotics in piglets (BARROS et al., 2008; MISSOTTEN et al., 2015).

\section{Effect of genetic line}

The observed difference in average daily feed intake between the genetic lines may be explained by the effect of heterosis obtained with the crossbreeding of two pure breeds, as well as to the higher number of Landrace $\mathrm{x}$ Large White crossbred piglets per sow in the present experiment. This result suggested that crossbred piglets were more active when seeking the feed to supply their daily nutritional needs. According to GIBSON et al. (2017) the individual's factors include variation in genetic predisposition to diseases, as well as specific polymorphisms in microbial recognition, which can influence colonization and its biological effects. Different from our findings, DE HAER \& MERKS (1992) and of LABROUE et al. (1997) indicated that feed intake has moderate heritability in Large White and Landrace pigs, which may suggest little 
influence of breed on this parameter. Conversely, BAAS et al. (1992) reported significantly higher daily feed intake in Hampshire $\mathrm{x}$ Landrace crossbred pigs compared with purebreds, indicating a strong effect of heterosis. In addition, comparing the feed intake behavior of pigs of different breeds, BAUMUNG et al. (2006) reported significant higher hourly feed intake in Landrace purebreds compared with Large White purebreds.

\section{CONCLUSION}

Piglets that received oral probiotics improved intestinal health and average daily weight gain, independent of the genetic lines. Higher duodenal villus were measured in P2 and P3 (450.37 $\mu \mathrm{m}$ and $435.62 \mu \mathrm{m}$, respectively) compared with the control group P1 (309.25 $\mu \mathrm{m} ; \mathrm{P}=0.01)$. Higher average daily weight gain was obtained in P2 and P3 (259.55 $\mathrm{g}$ and $250.50 \mathrm{~g}$, respectively) compared with P1 (221.9 g; $\mathrm{P}=0.02$ ). The use of probiotics must occur with the combination of appropriate bacteria. Variations in the intestinal microbiota and its effects can be affected by a variety of environmental and individual factors. Thus, the manipulation of the microbiota has the potential to vary its effect on an individual basis. This aspect may explain individual differences in the responsiveness and results of clinical trials. Due to challenges (i.e. heat or cold stress and immunological stress) in nowadays commercial pig units, the use of oral probiotic supplementation can be an alternative to improve gut health; and consequently, increase the average daily weight gain of suckling piglets and improve weaning weight, which can help with the post weaning feed intake adaptation.

\section{ACKNOWLEDGEMENTS}

The authors thank the Universidade Federal de Mato Grosso and the Coordenação de Aperfeiçoamento de Pessoal de Nível Superior (CAPES), Brasil.

\section{DECLARATION OF CONFLICT OF INTERESTS}

The authors declare no conflict of interest. The founding sponsors had no role in the design of the study; in the collection, analyses, or interpretation of data; in the writing of the manuscript, and in the decision to publish the results.

\section{AUTHORS' CONTRIBUTIONS}

The authors contributed equally to the manuscript.

\section{REFERENCES}

ASSIS, S. D., et al. Performance and morpho-intestinal characteristics of weaned gilts fed diets containing combinations with mannan oligosacharides. Archives of Veterinary Science. 19, p.33-41, 2014. Available from: <https://revistas.ufpr.br/veterinary/article/ view/35581>. Accessed: Jun. 22, 2020. doi: 10.5380/avs.v19i4.35581.

BAAS, T. J., et al. Heterosis and recombination effects in Hampshire and Landrace swine. J. Anim. Sci. 70, p.99-105, 1992. Available from: <https://pubmed.ncbi.nlm.nih.gov/1582926/>. Accessed: Jun 22, 2020. doi: 10.2527/1992.70199x.

BARROS, D. S., et al. Effect of the probiotic addition in diets of weaned piglets on the characteristics of the digesting system and of performance. Revista Brasileira de Saúde e Produção Animal. 9, p.469-479, 2008. Available from: <https://www.scielo.br/scielo. php?script $=$ sci_arttext\&pid=S1519-99402013000100009\&lng $=$ en\&nrm=iso\&tlng $=\mathrm{pt}>$. Accessed: Jun. 22, 2020. doi: 10.1590/ S1519-99402013000100009.

BAUMUNG, R., et al. Feed intake behavior of different pig breeds during performance testing on station. Archives Animal Breeding. 49, p.77-88, 2006. Available from: <https://aab.copernicus.org/ articles/49/77/2006/>. Accessed: Jun. 22, 2020. doi: 10.5194/aab49-77-2006, 2006.

BEHMER, O. A., et al. Manual de técnicas para histologia normal e patológica. First ed. São Paulo. Livraria Editora, 1976.

BOMBA, A., et al. Improvement of the probiotic effect of microorganisms by their combination with maltodextrins, fructooligosaccharides and polyunsaturated fatty acids. British journal of Nutrition. 88, p.95-99, 2002. Available from: <https://www. cambridge.org/core/journals/british-journal-of-nutrition/article/ improvement-of-the-probiotic-effect-of-microorganisms-by-theircombination-with-maltodextrins-fructooligosaccharides-andpolyunsaturated-fatty-acids/1D2A19EA1D1587310F4033DEE2F 2703D>. Accessed: Jun. 22, 2020. doi: 10.1079/BJN2002634.

BOSI, P., et al. Feed supplemented with 3 different antibiotics improved food intake and decreased the activation of the humoral immune response in healthy weaned pigs but had differing effects on intestinal microbiota. J. Anim. Sci. v.89, p.4043-4053, 2011. Available from: <http://www. journalofanimalscience.org/content/89/12/4043>. Accessed: Jun. 22, 2020. doi: 10.2527/jas.2010-3311 (originally published online July 1, 2011).

CHO, J. H., et al. Probiotics as a dietary additive for pigs: a review. Journal of Animal and Veterinary Advances. 10, p.2127-2134, 2011. Available from: <http://medwelljournals.com/abstract/?doi =javaa.2011.2127.2134>. Accessed: Jun. 22, 2020. doi: 10.3923/ javaa.2011.2127.2134.

CHOI, J. Y., et al. Effect of potential multimicrobe probiotic product processed by high drying temperature and antibiotic on performance of weanling pigs. Livest. Sci. 89, p. 1795-1804, 2011. Available from: <https://pubmed.ncbi.nlm.nih.gov/21278111/>. Accessed: Jun. 22, 2020. doi: 10.2527/jas.2009-2794.

DE HAER, L. C. M., MERKS, J. W. M. Patterns of daily food intake in growing pigs. Animal Science. 54, p.95-104, 1992. Available from: <https://www.cambridge.org/core/journals/animal-science/ article/patterns-of-daily-food-intake-in-growing-pigs/A2C5449E 
A69CE3A0C4B68282D11F763E>. Accessed: Jun. 22, 2020. doi: org/10.1017/S0003356100020614.

GIBSON, G. R., et al. The International Scientific Association for Probiotics and Prebiotics consensus statement on the definition and scope of prebiotics, Nature Reviews - Gastroenterology \& hepatology. Nature, USA, p.493-504, 2017. Available from: $<$ https://www.nature.com/articles/nrgastro.2017.75>. Accessed: Jun. 22, 2020. doi: 10.1038/nrgastro.2017.75.

GUEVARRA, R. B., et al. Piglet gut microbial shifts early in life: causes and effects. Journal of Animal Science and Biotechnology, 10:1, p.1-10, 2019. Available from: $<$ https://jasbsci.biomedcentral. com/articles/10.1186/s40104-018-0308-3>. Accessed: Jun. 22, 2020. doi: 10.1186/s40104-018-0308-3.

LABROUE, F., et al. Genetic parameters of feeding behavior and performance traits in group-housed Large White and French Landrace growing pigs. Genetics Selection Evolution. 29, p.451-468, 1997. Available from: <https://gsejournal. biomedcentral.com/articles/10.1186/1297-9686-29-4-451>. Accessed: Jun. 22, 2020. doi: 10.1186/1297-9686-29-4-451.

LIAO, S. F., et al. Using et al. probiotics to improve swine gut health and nutrient utilization. Animal Nutrition, 3, p.331-343, 2017. Available from: <https://www.sciencedirect.com/science/ article/pii/S2405654516302499>. Accessed: Jun. 22, 2020. doi: 10.1016/j.aninu.2017.06.007.

LUNA, U. V., et al. Mannan Oligosaccharides and ß-glucan in diets for weaned piglets. Arq. Bras. Med. Vet. Zootec. 67, p.591-599, 2015. Available from: <https://www.scielo. $\mathrm{br} / \mathrm{scielo.php}$ ?pid=S0102-09352015000200591\&script $=\mathrm{sci}$ abstract\&tlng=pt $>$. Accessed: Jun. 22, 2020. doi: 10.1590/1678-7146.

MISSOTTEN, J., et al. Fermented liquid feed for pigs: an ancient technique for the future. Journal of Animal Science and Biotechnology. 6, p.1-4, 2015. Available from: <https://jasbsci. biomedcentral.com/articles/10.1186/2049-1891-6-4>. Accessed: Jun. 22, 2020. doi: 10.1186/2049-1891-6-4.

NOBLET, J., ETIENNE, M. Estimation of sow milk nutrient output. J. Anim. Sci. 67, p.3352-3359, 1989. Available from: $<$ https://www.researchgate.net/publication/20541797_Estimation of Sow Milk Nutrient Output>. Accessed: Jun. 22, 2020. doi: 10.2527/jas 1989.67123352x.

ROBLES-HUAYNATE, R. A. et al. Effect of probiotic addition in diets of weaned piglets on the characteristics of the digesting system and performance. Revista Brasileira de Saúde e Produção Animal. 14, 2013. Available from: $<$ https://www.scielo.br/scielo.php?script $=$ sci arttext\&pid=S1519-99402013000100009\&lng=en\&nrm=iso\&tlng-pt $>$. Accessed: Jun. 22, 2020. doi: 10.1590/S1519-99402013000100009.

ROSTAGNO, H. S., et al. Tabelas brasileiras para aves e suínos: composição de alimentos e exigências nutricionais, third ed. UFV, Viçosa. 2011

SOBESTIANSKY, J., et al. Suinocultura intensiva: produção, manejo e saúde do rebanho, first ed. Embrapa, Brasília. 1998

TIZARD, I. R. Imunologia veterinária - uma introdução, sixth São Paulo : Roca, 2002

TSURUTA, T., et al. Commensal bacteria coated by secretory immunoglobulin A and immunoglobulin $\mathrm{G}$ in the gastrointestinal tract of pigs and calves. Animal Science Journal. 83, p.799804, 2012. Available from: <https://okayama.pure.elsevier. com/en/publications/commensal-bacteria-coated-by-secretoryimmunoglobulin-a-and-immun>. Accessed: Jun. 22, 2020. doi: 10.1111/j.1740-0929.2012.01026.x.

VALERIANO, V. D. V., et al. Probiotic roles of Lactobacillus sp. in swine: insights from gut microbiota. Journal of Applied Microbiology. 122, p.554-567, 2016. Available from: <https:// sfamjournals.onlinelibrary.wiley.com/doi/full/10.1111/ jam.13364>. Accessed: Jun. 22, 2020. doi: 10.1111/jam.13364.

VAN DER AAR, P. J. et al. The central role of intestinal health on the effect of feed additives on feed intake in swine and poultry. Anim Feed Sci technol. 233, p.64-75, 2017. Available from: <https://agris.fao.org/agris-search/search. do? recordID $=$ US201900129410 $>$. Accessed: Jun. 22, 2020. doi: 10.1016/j.anifeedsci.2016.07.019.

YANG, C. M., et al. Effect of chito-oligosaccharide on growth performance, intestinal barrier function, intestinal morphology and cecal microflora in weaned pigs. J. Anim. Sci. 90, p.26712676, 2012. Available from: <https://academic.oup.com/jas/ article-abstract $/ 90 / 8 / 2671 / 4702418$ ? redirectedFrom $=$ fullt ext $>$. Accessed: Jun. 22, 2020. doi: 10.2527/jas.2011-4699.

ŽIVKOVIĆ, B., et al. Prebiotics in nutrition of sows and piglets. Biotechnology in Animal Husbandry. 27, p.547-559, 2011. Available from: <http://www.doiserbia.nb.rs/Article. aspx?ID=1450-91561103547Z\#.XvEH0WhKhPY>. Accessed: Jun. 22, 2020. doi: 10.2298/BAH1103547Z. 